\title{
Afrina sporoboliae sp. n. (Nematoda: Anguinidae) Associated with Sporobolus cryptandrus from Idaho, United States: Phylogenetic Relationships and Population Structure
}

\author{
Bianca L. Barrantes-Infante, Brenda K. Schroeder, Sergei A. Subbotin, and Timothy D. Murray†
}

First and fourth authors: Department of Plant Pathology, Washington State University, Pullman 99164-6430; second author: Department of Entomology, Plant Pathology and Nematology, University of Idaho, Moscow 83844-2329; and third author: California Department of Food and Agriculture, Plant Pest Diagnostic Center, 3294 Meadowview Road, Sacramento 95832, and Center of Parasitology of A.N. Severtsov Institute of Ecology and Evolution of the Russian Academy of Sciences, Leninskii Prospect 33, Moscow, 117071, Russia.

Accepted for publication 9 January 2018.

\begin{abstract}
The dropseed gall-forming nematode, Afrina sporoboliae sp. n., is described from seed galls of Sporobolus cryptandrus (Poaceae: Chloridoideae: Sporobolinae) collected in Idaho, USA. This is the third report of an Afrina species in North America and the first report of this genus in a natural plant population on this continent. Morphological, morphometric, and molecular analyses placed this nematode in genus Afrina and demonstrated that it differs from Afrina hyparrheniae and Afrina spermophaga by having longer body and stylet lengths for females and males, and from Afrina wevelli by the absence of tip irregularities on the tails of female and presence of lips noticeably protruding beyond the body contour. The new species has several characters that overlap with Afrina tumefaciens, but differs from this species by inducing seed galls, whereas

Afrina tumefaciens induces ovoid galls on stems, leaves, and in flower heads. Evolutionary relationships of Afrina sporoboliae sp. n. with other representatives of the family Anguinidae are presented based on analysis of the internal transcribed spacer (ITS)1-5.8S-ITS2 rRNA and the D2-D3 regions of the rRNA genes. Analysis of 270 sequences of the coxl gene from 25 populations of Afrina sporoboliae sp. n. revealed seven haplotypes with sequence divergence up to $5 \%$. This study did not demonstrate a significant positive relationship between genetic difference and geographic distance. Seed gall nematodes are important quarantine pests in many countries. The association of this and other seed gall nematodes with Rathayibacter species and their ability to serve as vectors, especially of $R$. toxicus, is of concern for U.S. agriculture.
\end{abstract}

Plant-parasitic nematodes in the family Anguinidae Nicoll, 1935 are obligate specialized parasites of higher plants, mosses, and seaweeds that often induce swellings and galls on their hosts. Several species in this family are considered economically important agricultural and quarantine pests in various countries and are internationally regulated in many countries (Subbotin and Riley 2012). The validities and taxonomic positions of several genera and subfamilies have been the subject of intensive discussions and speculation (Brzeski 1981; Chizhov and Subbotin 1985, 1990; Fortuner and Maggenti 1987; Siddiqi 2000) and remain unresolved. The genus Afrina is comprised of four species: Afrina hyparrheniae (Corbett 1966) Brzeski 1981; Afrina tumefaciens (Cobb 1932) Brzeski 1981; Afrina spermophaga (Steiner 1937) Van den Berg 1985; and Afrina wevelli Van den Berg 1985 (Brzeski 1981; Van den Berg 1985). Representatives of this genus cause galls in seeds, stems, and leaves of grasses in the subfamilies Panicoideae and Chloridoideae, and presently are known from Africa, Asia, Australia, and North America (Subbotin and Riley 2012). Afrina wevelli was found forming galls on the seeds of Eragrostis curvula (Schrad.) Nees in South Africa, an important forage grass in the area, becoming an important problem for the seed export industry (Subbotin and Riley 2012). The main

${ }^{\dagger}$ Corresponding author: T. D. Murray; E-mail: tim.murray@wsu.edu

Funding: Financial support was provided by the 2008 Farm Bill, Section 10201 administered through the United States Department of Agriculture (USDA) Animal and Plant Health Inspection Service (13-8130-0247-CA and 14-8130-0367-CA) and the Emerging Research Issues Program funded by the Washington State University Agricultural Research Center. PPNS 0753, Department of Plant Pathology, College of Agricultural, Human, and Natural Resource Sciences, Agricultural Research Center, Hatch Project WNP00670, Washington State University, Pullman.

(C) 2018 The American Phytopathological Society difference between Afrina and other genera in the subfamily Anguininae, particularly the genus Anguina, is structure of the female genital system. Specifically, the crustaformeria of Afrina species is formed by four rows with 14 cells per row in contrast to Anguina species with 6 to 12 rows with 20 to 60 cells per row (Brzeski 1981). In both genera, the second-stage juveniles are the infective stage (Subbotin and Riley 2012).

Anguina species can act as vectors of bacterial plant pathogens in the genus Rathayibacter (Price et al. 1979; Riley and McKay 1990). For example, in Australia, Anguina tritici is the vector of $R$. tritici (Carlson and Vidaver 1982) Zgurskaya et al. 1993 (Riley and Reardon 1995), Anguina funesta (Fisher et al. 1979), Anguina australis (Riley et al. 2001), and Anguina paludicola (Bertozzi and Davies 2009) are vectors of the bacterium $R$. toxicus (Riley and Ophel 1992) Sasaki et al. 1998, causal agent of gummosis or yellow slime disease of annual ryegrass (Lolium multiflorum Lam.) (Chatel et al. 1979; Riley 1987).

Rathayibacter toxicus is listed as a quarantine organism by USDA-APHIS in the prioritized offshore pest list (OPIS 2012) because it produces corynetoxins, which result in annual ryegrass toxicity and poisoning of livestock (Chatel et al. 1979; Edgar et al. 1982). Only $R$. toxicus is known to produce corynetoxins (McKay and Ophel 1993), although $R$. iranicus and a Rathayibacter species isolated from Ehrhata villosa Schult. f. var. villosa in South Africa are suspected toxin producers (Murray et al. 2017). Anguina funesta has been found in Oregon, USA, but $R$. toxicus has not (Meng et al. 2012); however, special attention is needed because Anguina funesta is already present in the United States (Meng et al. 2012); therefore, establishment of the bacteria could be easier.

Little is known about the incidence and distribution of Afrina or Anguina species in native grasses or those under cultivation (wheat, ryegrass, bluegrass, orchard grass, and timothy grass) in the United 
States, or their potential association with bacteria in the genus Rathayibacter. Quarantine measures and methods for identification of pathogens and vectors are needed to rapidly and accurately identify and distinguish among both.

The purpose of this study was to characterize a previously unidentified species of Afrina associated with sand dropseed, Sporobolus cryptandrus (Torr.) A. Gray collected in West Central Idaho, USA, and to describe it as a new species using morphological and molecular data. This nematode was first found by L. Carris (Washington State University) in Idaho and later sequenced by Li et al. (2015). Our study provides a morphological description of this nematode, its evolutionary relationship to other anguinids, and provides a preliminary study of the genetic structure and diversity of this new nematode species.

\section{MATERIALS AND METHODS}

Nematode sampling. Samples of the grass Sporobolus cryptandrus exhibiting seed galls were collected in spring through summer 2013 to 2016 near White Bird, Idaho and southward along Highway 95, Idaho from 25 sites (Table 1; Fig. 1). Collection sites (hereafter called "populations") were chosen randomly and most of the sites were located along roadsides. However, some collection sites were located in the White Bird Battlefield area, which belongs to the Nez Perce National Historical Park (Permit NEPE-2015-SCI-0002) managed by National Park Service, U.S. Department of Interior. Each sample consisted of stems and seed heads of one plant, stored in paper or plastic bags at room temperature until processed. Each sample was inspected for the presence of seed galls in the laboratory and one seed gall per sample was placed in a small petri dish $(35 \times 10 \mathrm{~mm})$ containing $1 \mathrm{ml}$ of sterile water and evaluated for the presence of nematodes. Nematodes were obtained from 25 populations and characterized using molecular markers (Table 1).

Two other anguinid nematodes were included in the molecular analysis: a seed gall sample of Anguina agropyronifloris infecting Agropyron smithii obtained from the Washington State University
Mycological Herbarium (WSP25591) collected in 1950 in Tres Piedras, New Mexico, USA, and a sample of Anguina agrostis infecting Agrostis sp. collected in the Olympic National Park, WA, USA in 2014.

Morphological analysis. Fresh seed galls were collected from S. cryptandrus in spring 2016 near White Bird, Idaho and south on Highway 95, Idaho and used for the morphological characterization. Nematodes were killed by heating, fixed in $4 \%$ formalin, transferred to dehydrated glycerin, and mounted on permanent slides (De Grisse 1969). Measurements of characters for species description were made from specimens killed by heating and mounted into temporary slides. Photomicrographs of adults and juveniles were taken with an Olympus Infinity 2 automatic camera attached to an Olympus BX51 compound microscope equipped with a Nomarski differential interference contrast.

DNA extraction, PCR, and sequencing. DNA was extracted from single nematodes using QIAamp DNA Micro Kit (Qiagen, Hilden, Germany). A total of 10 nematodes per seed gall were handpicked and each nematode was placed separately into a $1.5-\mathrm{ml}$ tube with $200 \mu \mathrm{l}$ buffer ATL and $20 \mu \mathrm{l}$ of Proteinase K. The samples were incubated on a ThermoMixer C heated shaker (Eppendorf, Hamburg, Germany) at $58^{\circ} \mathrm{C}$ and $300 \mathrm{rpm}$ for $20 \mathrm{~h}$ Then, $200 \mu \mathrm{l}$ of Buffer AL and $1 \mu \mathrm{g}$ of dissolved carrier ARN was added to each tube, incubated for $5 \mathrm{~min}$ at $70^{\circ} \mathrm{C}$, mixed on a vortex mixer for 5 to $10 \mathrm{~s}$, and then incubated again for $5 \mathrm{~min}$ at $70^{\circ} \mathrm{C}$. Subsequent steps were performed following the instructions for the isolation of genomic DNA in the QIAamp DNA Handbook 2010. Different quantities of DNA from single nematode extractions were used initially to determine which amount resulted in the best amplification; all subsequent reactions used $3 \mu$ of DNA.

The internal transcribed spacer (ITS) rRNA gene, the D2-D3 regions of the $28 \mathrm{~S}$ rRNA gene, and the partial cytochrome c oxidase I (coxl) gene of the mitochondrial DNA (mtDNA) were used for molecular characterization. Primers TW81 (5'-GTT TCC GTA GGT GAA CCT GC-3') and AB28 (5'-ATA TGC TTA AGT TCA GCG GGT-3')

TABLE 1. Sampling locations of the seed gall nematode Afrina sporoboliae sp. n. from central Idaho, USA, and their coxl, internal transcribed spacer (ITS) rRNA, and D2-D3 haplotypes

\begin{tabular}{|c|c|c|c|c|c|c|c|c|c|}
\hline \multirow[b]{2}{*}{ Site ID } & \multirow[b]{2}{*}{ GPS coordinates } & \multicolumn{4}{|c|}{$\operatorname{Cox} 1$} & \multicolumn{2}{|r|}{ ITS } & \multicolumn{2}{|c|}{ D2-D3 } \\
\hline & & $\begin{array}{c}\text { Number } \\
\text { of samples }\end{array}$ & Haplotypes $^{\mathrm{a}}$ & $h^{\mathrm{b}}$ & $\pi^{\mathrm{c}}$ & $\begin{array}{c}\text { Number } \\
\text { of samples }\end{array}$ & Haplotypes & $\begin{array}{c}\text { Number } \\
\text { of samples }\end{array}$ & Haplotypes \\
\hline S1 & $\mathrm{N} 45^{\circ} 37.308, \mathrm{~W} 116^{\circ} 17.821$ & 20 & H1 (7), H2 (13) & 0.4789 & 0.0007 & 30 & $\operatorname{Ail}(30)$ & & - \\
\hline $\mathrm{S} 2$ & $\mathrm{~N} 45^{\circ} 44.288, \mathrm{~W} 116^{\circ} 18.865$ & 10 & H1 (10) & 0 & 0 & 20 & $\operatorname{Ail}(14), \operatorname{Ai2}(6)$ & 10 & Aidl(10) \\
\hline S3 & $\mathrm{N} 45^{\circ} 46.344, \mathrm{~W} 116^{\circ} 17.847$ & 10 & H1 (5), H5 (5) & 0.5556 & 0.0051 & 50 & $\operatorname{Ail}(50)$ & & - \\
\hline S4 & $\mathrm{N} 45^{\circ} 48.104, \mathrm{~W} 116^{\circ} 16.193$ & 10 & H3 (10) & 0 & 0 & 10 & $\operatorname{Ail}(10)$ & 10 & Aidl(10) \\
\hline S5 & $\mathrm{N} 45^{\circ} 37.501, \mathrm{~W} 116^{\circ} 18.221$ & 20 & H3 (20) & 0 & 0 & 20 & $\operatorname{Ail}(20)$ & 10 & Aidl(10) \\
\hline S6 & $\mathrm{N} 45^{\circ} 37.171, \mathrm{~W} 116^{\circ} 17.345$ & 10 & H1 (10) & 0 & 0 & 10 & Ail(10) & & - \\
\hline S7 & $\mathrm{N} 45^{\circ} 37.174, \mathrm{~W} 116^{\circ} 16.747$ & 10 & $\mathrm{H} 1$ (5), H2 (5) & 0.5556 & 0.0008 & 10 & $\operatorname{Ail}(10)$ & & - \\
\hline S8 & $\mathrm{N} 45^{\circ} 38.779, \mathrm{~W} 116^{\circ} 17.556$ & 10 & H1 (10) & 0 & 0 & 10 & Ail(10) & & - \\
\hline S9 & $\mathrm{N} 45^{\circ} 47.594, \mathrm{~W} 116^{\circ} 16.275$ & 10 & H1 (10) & 0 & 0 & 10 & $\operatorname{Ail}(10)$ & & - \\
\hline S10 & $\mathrm{N} 45^{\circ} 48.181, \mathrm{~W} 116^{\circ} 15.984$ & 10 & H1 (10) & 0 & 0 & 10 & Ail(10) & & - \\
\hline S11 & $\mathrm{N} 45^{\circ} 48.080, \mathrm{~W} 116^{\circ} 16.060$ & 10 & H1 (10) & 0 & 0 & 10 & $\operatorname{Ail}(10)$ & & - \\
\hline $\mathrm{S} 12$ & $\mathrm{~N} 45^{\circ} 48.228, \mathrm{~W} 116^{\circ} 16.221$ & 10 & $\mathrm{H} 2(10)$ & 0 & 0 & 10 & $\operatorname{Ail}(10)$ & & - \\
\hline S13 & $\mathrm{N} 45^{\circ} 47.762, \mathrm{~W} 116^{\circ} 15.870$ & 10 & $\mathrm{H} 2(5), \mathrm{H} 3(5)$ & 0.5556 & 0.0286 & 10 & $\operatorname{Ail}(10)$ & & - \\
\hline S14 & $\mathrm{N} 45^{\circ} 48.068, \mathrm{~W} 116^{\circ} 17.271$ & 10 & $\mathrm{H} 2(10)$ & 0 & 0 & 10 & $\operatorname{Ail}(10)$ & & - \\
\hline S15 & $\mathrm{N} 45^{\circ} 26.823, \mathrm{~W} 116^{\circ} 18.669$ & 10 & $\mathrm{H} 2(10)$ & 0 & 0 & 10 & $\operatorname{Ail}(10)$ & & - \\
\hline S16 & $\mathrm{N} 45^{\circ} 36.828, \mathrm{~W} 116^{\circ} 16.892$ & 10 & $\mathrm{H} 2(10)$ & 0 & 0 & 10 & $\operatorname{Ail}(10)$ & & - \\
\hline S17 & $\mathrm{N} 45^{\circ} 39.300, \mathrm{~W} 116^{\circ} 17.482$ & 10 & $\mathrm{H} 4$ (10) & 0 & 0 & 10 & $\operatorname{Ail}(10)$ & 10 & $\operatorname{Aidl}(10)$ \\
\hline S18 & $\mathrm{N} 45^{\circ} 28.817, \mathrm{~W} 116^{\circ} 18.848$ & 10 & H1 (7), H5 (3) & 0.4667 & 0.0043 & 10 & $\operatorname{Ail}(10)$ & & - \\
\hline S19 & $\mathrm{N} 45^{\circ} 31.520, \mathrm{~W} 116^{\circ} 18.276$ & 10 & H1 (10) & 0 & 0 & 10 & $\operatorname{Ail}(10)$ & & - \\
\hline S20 & $\mathrm{N} 45^{\circ} 46.958, \mathrm{~W} 116^{\circ} 16.460$ & 10 & $\mathrm{H} 2(10)$ & 0 & 0 & 10 & $\operatorname{Ail}(10)$ & & - \\
\hline S21 & $\mathrm{N} 45^{\circ} 47.111, \mathrm{~W} 116^{\circ} 16.360$ & 10 & H1 (10) & 0 & 0 & 10 & $\operatorname{Ail}(10)$ & & - \\
\hline S22 & $\mathrm{N} 45^{\circ} 47.215, \mathrm{~W} 116^{\circ} 16.540$ & 10 & $\mathrm{H} 2(10)$ & 0 & 0 & 10 & $\operatorname{Ail}(10)$ & & - \\
\hline $\mathrm{S} 23$ & $\mathrm{~N} 45^{\circ} 46.860, \mathrm{~W} 116^{\circ} 16.868$ & 10 & $\mathrm{H} 2$ (6), H3 (4) & 0.5333 & 0.0275 & 10 & $\operatorname{Ail}(10)$ & & - \\
\hline S24 & $\mathrm{N} 45^{\circ} 46.953, \mathrm{~W} 116^{\circ} 16.678$ & 10 & $\mathrm{H} 2$ (10) & 0 & 0 & 10 & $A i 1(8), A i 2(2)$ & 10 & $\begin{array}{l}\operatorname{Aid1}(5), \operatorname{Aid} 2(3), \\
\quad \operatorname{Aid} 3(2)\end{array}$ \\
\hline S25 & $\mathrm{N} 45^{\circ} 49.201, \mathrm{~W} 116^{\circ} 16.424$ & 10 & H3 (2), H6 (6), H7 (2) & 0.6222 & 0.0203 & 10 & $\operatorname{Ail}(8), \operatorname{Ai2}(2)$ & 10 & $\operatorname{Aidl}(10)$ \\
\hline
\end{tabular}

a Number of identical sequences are given in parentheses.

b $h=$ haplotype diversity.

c $\pi=$ nucleotide diversity. 
were used to amplify the 18S rRNA gene (partially), ITS1, 5.8S, ITS2, and 28S rRNA gene (partially) (Joyce et al. 1994; Zheng et al. 2000) and primers D2A (5'-ACA AGT ACC GTG AGG GAA AGT TG-3') and D3B (5'-TCG GAA GGA ACC AGC TAC TA-3') to amplify (partially) the D2-D3 region of the 28S rRNA gene (Subbotin et al. 2005). Primers COI-F1 (5'-CCT ACT ATG ATT GGT GGT TTT GGT AAT TG-3') and COI-R2 (5'-GTA GCA GCA GTA AAA TAA GCA CG- $3^{\prime}$ ) were used to amplify (partially) the coxl gene of the mtDNA (Futai and Kanzaki 2002).

PCR was performed in $25-\mu \mathrm{l}$ volumes that included $0.5 \mu \mathrm{M}$ of each primer, $1 \times$ Phusion HF buffer (New England BioLabs, Ipswich, MA), $200 \mu \mathrm{M}$ dNTP mix (New England BioLabs), $0.5 \mathrm{mM} \mathrm{MgCl} \mathrm{Mg}_{2}$ (New England BioLabs), 0.5 U Phusion High-Fidelity DNA polymerase (New England BioLabs), and $3 \mu \mathrm{l}$ of the crude DNA extract from a single nematode. Amplification of the ITS region consisted of an initial denaturation at $98^{\circ} \mathrm{C}$ for $30 \mathrm{~s}$, followed by 35 cycles of denaturation at $98^{\circ} \mathrm{C}$ for $5 \mathrm{~s}$, annealing at $60^{\circ} \mathrm{C}$ for $20 \mathrm{~s}$, and extension at $72^{\circ} \mathrm{C}$ for $30 \mathrm{~s}$. The final extension was at $72^{\circ} \mathrm{C}$ for $5 \mathrm{~min}$. Amplification conditions for the D2-D3 region and partial coxl gene were the same as for the ITS region except the annealing temperature, which was 57 and $55^{\circ} \mathrm{C}$, respectively. All PCR reactions were carried out in a T100 Thermal cycler (Bio-Rad Laboratories, Hercules, CA). PCR products were separated by electrophoresis in $1 \times$ TAE buffer, $1 \%$ agarose gel and SYBR safe stain (Invitrogen, Carlsbad, CA) was used to detect the bands.

PCR products were purified using the GeneJET PCR Purification Kit (Thermo Fisher Scientific, Hampton, NH) according to manufacturer's instructions. DNA quantification was made using a Nanodrop ND-1000 spectrophotometer (NanoDrop, Wilmington, DE). Each PCR product was sequenced in both forward and reverse directions by Elim Biopharmaceuticals (Hayward, CA) using the $\mathrm{GC}$ rich protocol. The new sequences were submitted to the GenBank database under the accession numbers: MG321198 to MG321217.

Sequence and phylogenetic analyses. Sequences from 10 juveniles/gall/plant from each population were used in most analyses of the ITS region and partial coxl gene (Table 1). For some populations, sequences were obtained from more than one plant to determine whether more variation would be detected with a larger sample size. Consequently, more than 10 sequences were used in four populations (S1, S2, S3, and S5) for the ITS analysis resulting in a total of 330 sequences from 25 populations, and 20 sequences
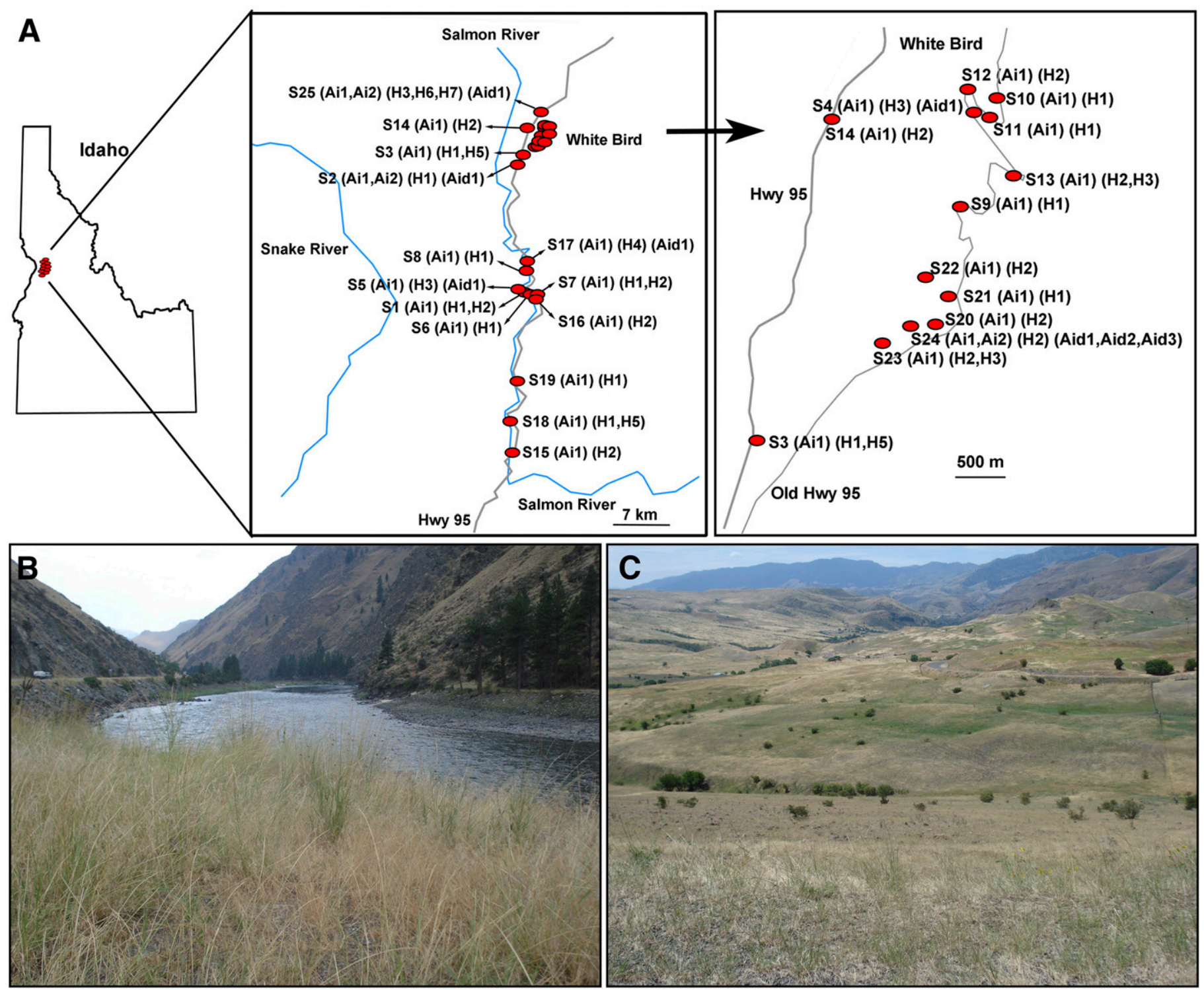

Fig. 1. A, Map showing locations of the 25 populations of Sporobolus cryptandrus that tested positive for the dropseed gall-forming nematode Afrina sporoboliae sp. n. sampled for this study. Photographs (June 2015) of two different collection sites along B, Highway 95 (Table 1; near site S1 looking south) and C, White Bird Battlefield area (Table 1; near site S4 looking south). 
from populations S1 and S5 were used for the partial coxl gene, resulting in a total of 270 sequences (Table 1). Ten sequences/ population from six populations (S2, S4, S5, S17, S24, and S25) were used in the analysis of the D2-D3 region of the 28S nuclear rRNA gene. These six populations were chosen based on variability of the ITS and partial coxl haplotypes. Ten sequences each from galls in the Agrostis sp. and Agropyron smithii samples were used in the ITS, partial coxl, and D2-D3 analyses. Each sequence came from a single nematode and only unique sequences were used in the phylogenetic analyses.

Sequences of the D2-D3 region of the 28S rRNA and ITS rRNA genes were aligned using ClustalX 1.83 (Thompson et al. 1997) with their corresponding published gene sequences of anguinid nematodes (Bertozzi and Davies 2009; Li et al. 2015; MedinaGómez et al. 2016; Mobasseri et al. 2017; Powers et al. 2001; Subbotin et al. 2004, 2005; Zhao et al. 2011). Sequences were analyzed with Bayesian inference (BI) using MrBayes 3.1.2 (Huelsenbeck and Ronquist 2001). Models of DNA evolution for BI were estimated using MrModeltest 2.2 and the best-fit was chosen using the Akaike Information Criterion (Nylander 2002). BI analysis under the GTR $+\mathrm{I}+\mathrm{G}$ model was initiated with a random starting tree and run with the four Metropolis-coupled Markov chain Monte Carlo (MCMC) for $10^{6}$ generations. The MCMC were sampled at intervals of 100 generations. The log-likelihood values of the sample points stabilized after approximately $10^{3}$ generations. After discarding burn-in samples and evaluating convergence the remaining samples were retained for further analysis. The topologies were used to generate a $50 \%$ majority rule consensus tree. Posterior probabilities (PP) more than $70 \%$ are given for appropriate clades.

Population structure analysis. Pairwise sequence divergence among populations for the coxl data were estimated using MEGA6 (Tamura et al. 2013). DnaSP 5.10 (Librado and Rozas 2009) estimated the molecular diversity, including the number of segregating sites, number of haplotypes, haplotype diversity, and nucleotide diversity. Arlequin version 3.5.1.2 (Excoffier and
Lischer 2010) software performed an analysis of molecular variance (AMOVA) to analyze the pairwise differences among and within collections. A minimum-spanning haplotype network was created in PopART version 1.7 (Leigh and Bryant 2015).

\section{RESULTS}

Nematode samples. Forty-six samples positive for seed gall nematodes were obtained from 25 populations of Sporobolus cryptandrus in Idaho, specifically near White Bird (Old White Bird grade and White Bird Battlefield area) and south along Highway 95. Each site positive for the presence of nematodes was considered as a collection, labeled as S1 to S25 (Table 1; Fig. 1). All grasses positive for the presence of seed galls (Fig. 2) belong to the species Sporobolus cryptandrus and the majority of infected plants, showed rolling or twisting leaves. There were no apparent differences in symptoms among collections.

Here we provide description of this new seed gall nematode under the common name, the dropseed gall-forming nematode, Afrina sporoboliae sp. n. (Figs. 3, 4, 5, and 6).

Measurements and description. Hoplotype female. $\mathrm{L}$ (length) $=$ $2,247 \mu \mathrm{m} ; \mathrm{a}$ (length/greatest width) $=24.9 ; \mathrm{b}$ (length/ length of esophagus from anterior end) $=11.2 ; \mathrm{V}$ (distance to vulva from anterior end expressed as a percentage of the total length) $=95 \%$; stylet length $=8.1 \mu \mathrm{m}$, anterior end to the valve of median bulb $=$ $77.5 \mu \mathrm{m}$; pharynx length $=200 \mu \mathrm{m}$; anterior end to excretory pore $=$ $167.5 \mu \mathrm{m}$; maximum width $=90 \mu \mathrm{m}$.

Paratype females $(\mathrm{n}=15)$. $\mathrm{L}=2,021 \pm 267.3(1,695$ to 2,570$) \mu \mathrm{m}$; $\mathrm{a}=22.4 \pm 2.9$ (18.0 to 27.8$) ; \mathrm{b}=9.5 \pm 1.9$ (7.0 to 13.0$) ; \mathrm{V}=93.6 \pm 1.5$ (90.6 to 95.3$) \%$; stylet length $=8.8 \pm 0.8$ (7.5 to 10$) \mu \mathrm{m}$; lip region high $=2.3 \pm 0.2$ (1.9 to 2.5$) \mu \mathrm{m}$; lip region width $=6.2 \pm 0.3$ (5.6 to 6.6) $\mu \mathrm{m} ; \mathrm{DGO}=2.2 \pm 0.3$ (1.9 to 2.6$) \mu \mathrm{m}$; pharynx length $=219 \pm$ $42(150$ to 300$) \mu \mathrm{m}$; anterior end to the valve of median bulb $=$ $61.5 \pm 7.1(52.5$ to 82.5$) \mu \mathrm{m}$; median bulb length $=18.8 \pm 0.6(17.5$ to 20$) \mu \mathrm{m}$; median bulb width $=16.9 \pm 1.0$ (15 to 18.8$) \mu \mathrm{m}$; anterior end to excretory pore $=159.8 \pm 18.9$ (125 to 200$) \mu \mathrm{m}$;
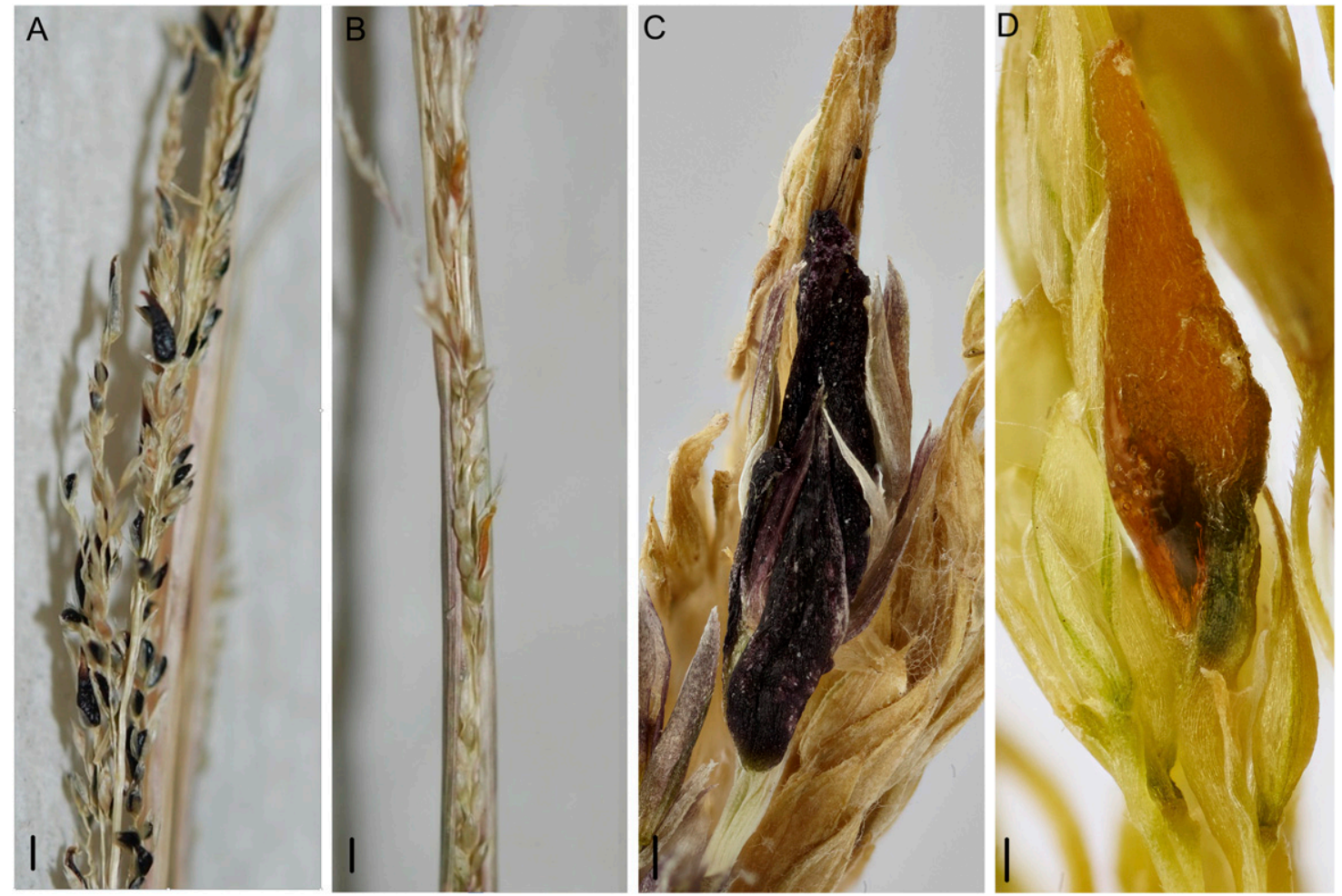

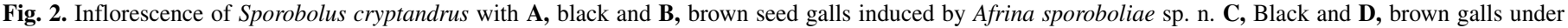
higher magnification. Scale bars: $\mathbf{A}$ and B, $1 \mathrm{~mm} ; \mathbf{C}$ and $\mathbf{D}, 0.15 \mathrm{~mm}$. 
maximum width $=91 \pm 11.4$ (67.5 to 110$) \mu \mathrm{m}$; width at excretory pore $=52.9 \pm 4.7$ (45 to 62.5$) \mu \mathrm{m}$; width at vulva $=51.1 \pm 3.1$ (45 to 55) $\mu \mathrm{m}$; post-uterine sac $=52.3 \pm 5.8$ (45 to 62.5$) \mu \mathrm{m}$.

Body coiled, very stout, tapering rapidly to both ends, anteriorly from pharyngeal base, posteriorly from vulva. Lips flattened anteriorly, not annulated, distinctly set off from the body. Stylet short, with rounded knobs. Cuticle finely annulated. Lateral field consisting of two marginal lines and no incisures visible between marginal lines. Procorpus more or less cylindroid, sometimes slightly set off from ovoid median bulb. Basal bulb large, forming a long lobe overlapping. Hemizonid not seen. Ovary double reflexed. Crustaformeria with four rows, 14 cells per a row. Vulva in form of a transverse slit, lips noticeably protruding beyond body contour. Detail of reproductive system not clearly seen. Post-uterine branch sac-like, reaching 34 to $62 \%$ of distance between vulva and tail terminus. Anus not visible. Tail tapering gradually to a minutely pointed terminus.

Paratype males $(\mathrm{n}=12) . \mathrm{L}=1,586 \pm 133.3(1,325$ to 1,788$) \mu \mathrm{m}$; $\mathrm{a}=37.8 \pm 4.6(30.7$ to 47.7$) ; \mathrm{b}=9.7 \pm 0.9$ (7.5 to 11.2$)$; stylet length $=$ $8.7 \pm 0.8$ (7.5 to 10$) \mu \mathrm{m}$; lip region high $=2.2 \pm 0.2$ (1.6 to 2.5$) \mu \mathrm{m} ;$ lip region width $=6.4 \pm 0.4$ (6 to 7.5$) \mu \mathrm{m} ; \mathrm{DGO}=2.0 \pm 0.3$ (1.6 to 2.3 ) $\mu \mathrm{m}$; pharynx length $=162.2 \pm 14.8$ (125 to 175$) \mu \mathrm{m}$; anterior end to the valve of median bulb $=63 \pm 4.8$ (37.5 to 50) $\mu \mathrm{m}$; median bulb length $=$ $16.6 \pm 1.1$ (15 to 17.5$) \mu \mathrm{m}$; median bulb width $=14.5 \pm 1.6$ (12.5 to 17.5) $\mu \mathrm{m}$; anterior end to excretory pore $=138.2 \pm 19.4$ (100 to 162.5) $\mu \mathrm{m}$; maximum width $=42.3 \pm 4.6$ (37.5 to 50$) \mu \mathrm{m}$; width at excretory pore $=32.5 \pm 4.7$ (27.5 to 40$) \mu \mathrm{m}$; tail length $=53.5 \pm 4.6(45$ to 62.5$)$ $\mu \mathrm{m}$; spicules $=43.3 \pm 3.3$ (40.5 to 51$) \mu \mathrm{m}$; gubernaculum $=17.3 \pm 2.5$ (13.5 to 19.5$) \mu \mathrm{m}$.

Morphology of male as in female except for several following characters. Body more slender than that of female. Lip region flattened anteriorly, not set off from whole body. Spicules ventrally curved, gubernaculum slightly ventrally curved. Bursa reaching tail tip. Tail terminus with mucro.
Paratype second-stage juveniles $(\mathrm{n}=14) . \mathrm{L}=719.5 \pm 54.2(612$ to 802$) \mu \mathrm{m} ; \mathrm{a}=36.6 \pm 2.9(30.6-40.4) ; \mathrm{b}=4.6 \pm 0.3(4.1$ to 5.3$) ; \mathrm{c}=$ $15.9 \pm 2.7(12.3$ to 21.2$)$; stylet length $=9.6 \pm 0.5$ (8.8 to 10$) \mu \mathrm{m}$; anterior end to the valve of median bulb $=57.2 \pm 6.7$ (43.8 to 65$) \mu \mathrm{m}$; anterior end to excretory pore $=100 \pm 6.9(87$ to 109$) \mu \mathrm{m}$; pharynx length $=156.6 \pm 14.4(125$ to 178$) \mu \mathrm{m} ;$ body width $=19.5 \pm 0.9(17.5$ to 21.3$) \mu \mathrm{m}$; tail length $=45.8 \pm 5.5$ (37.5 to 52.5$) \mu \mathrm{m}$.

Body slightly curved to almost straight. Lip region very slightly offset. Stylet small with delicate, rounded, knobs. Pharyngeal lobe long, slightly overlapping intestine. Lateral filed with four incisures. Tail long, tapering very gradually to an acute tip without mucro.

Eggs $(\mathrm{n}=12) . \mathrm{L}=63.6 \pm 3.7(57.5$ to 70.0$) \mu \mathrm{m} ; \mathrm{W}=31.5 \pm 1.1$ (30.0 to 32.5$) \mu \mathrm{m} ; \mathrm{L} / \mathrm{W}=2.1 \pm 0.5$ (1.8 to 3.7 ).

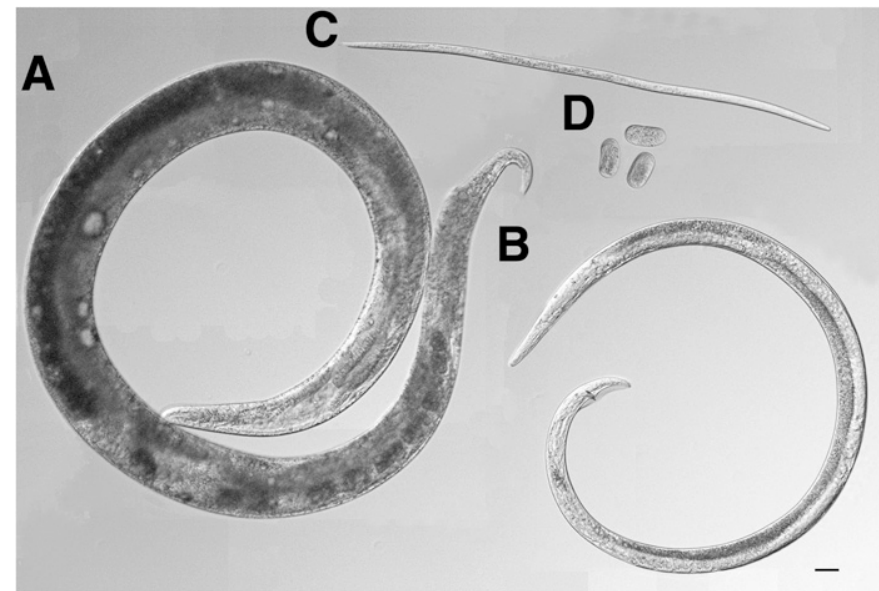

Fig. 4. Afrina sporoboliae sp. $\mathrm{n} .:$ A, female; $\mathbf{B}$, male; $\mathbf{C}$, second-stage juveniles; and $\mathbf{D}$, eggs. Scale bar $=40 \mu \mathrm{m}$.

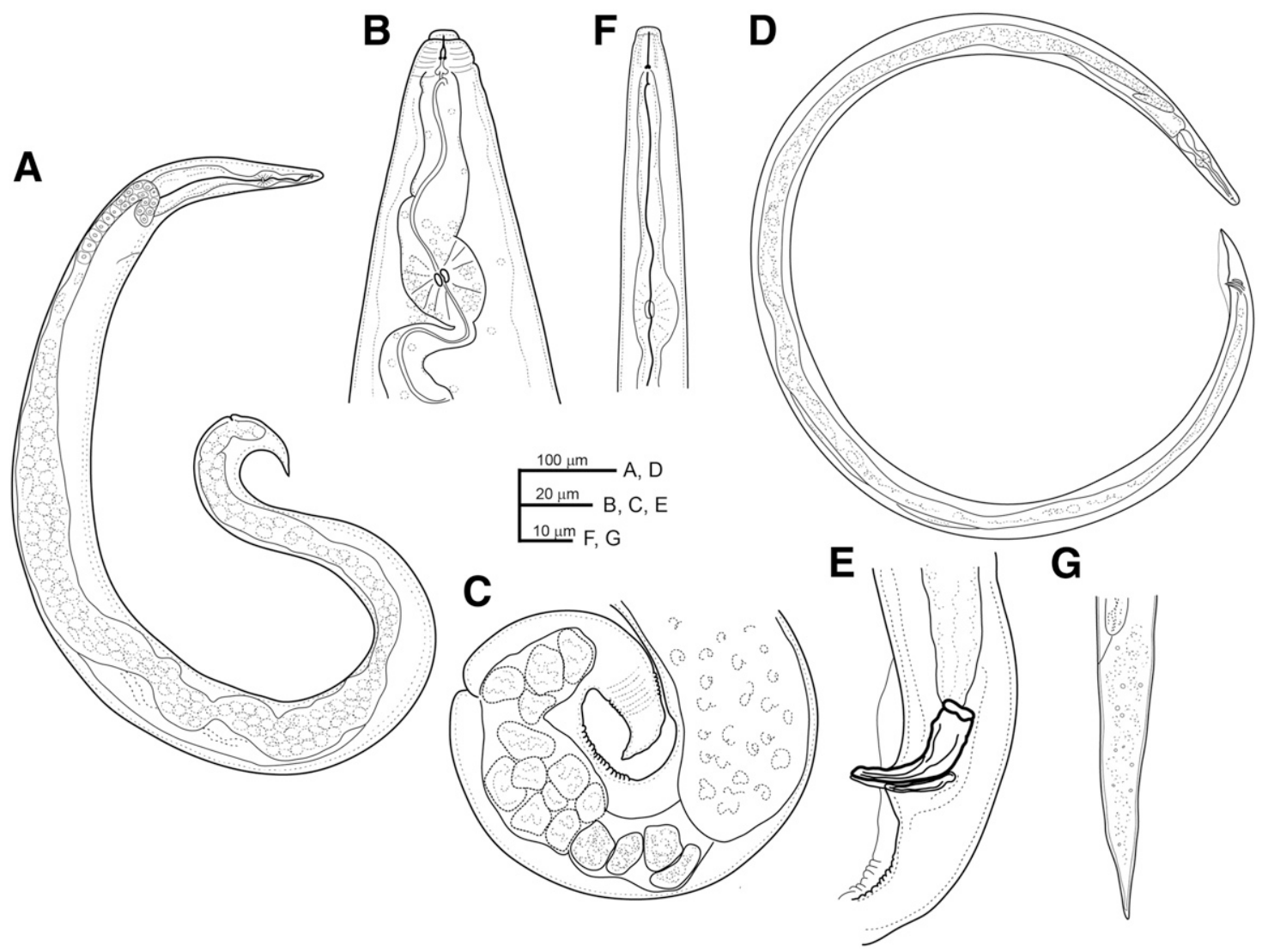

Fig. 3. Afrina sporoboliae sp. n.: A, female entire body; B, female anterior end; $\mathbf{C}$, female posterior end; $\mathbf{D}$, male entire body; $\mathbf{E}$, spicules; $\mathbf{F}$, second-stage juvenile anterior; and $\mathbf{G}$, second-stage juvenile tail region. 
Differential diagnosis. Afrina sporoboliae is morphologically similar with other Afrina species: Afrina hyparrheniae, Afrina tumefaciens, Afrina spermophaga, and Afrina wevelli. It differs from Afrina hyparrheniae by longer body lengths for females and males (1,695 to 2,570 and 1,325 to $1,788 \mu \mathrm{m}$ versus 1,510 to 1,840 and 1,260 to $1.390 \mu \mathrm{m}$, respectively) and longer stylet for females and males ( 7.5 to 10 and 7.5 to $10 \mu \mathrm{m}$ versus 7 to 8 and 6 to $7 \mu \mathrm{m}$, respectively); from Afrina wevelli by absence of tip irregularities on tails of female and presence of lips noticeably protruding beyond body contour; and from Afrina spermophaga by longer body lengths for females and males (1,280 to 1,700 and 960 to $1,400 \mu \mathrm{m}$ in Afrina spermophaga) and longer stylet for females and males (6.6 to 7.4 and 5.5 to $7.0 \mu \mathrm{m}$ in Afrina spermophaga). The new species overlaps in morphometrics of many characters with Afrina tumefaciens and differs from this species by inducing seed galls, whereas Afrina tumefaciens induces ovoid galls 2 to $8 \mathrm{~mm}$ long on stems, leaves, and in flower heads (Krall 1991).

Type host. Sand dropseed, Sporobolus cryptandrus (Poaceae: Chloridoideae: Sporobolinae).
Symptoms. Nematodes induced seed galls. Mature seed galls varied in color from purplish to light brown and usually 1.5 to $2.2 \mathrm{~mm}$ in a length (Fig. 2). Infected plants also showed rolling or twisting leaves.

Type locality. United States, Idaho. GPS coordinates: $45^{\circ} 37^{\prime} 50.1^{\prime \prime} \mathrm{N}$, $116^{\circ} 18^{\prime} 22.1^{\prime \prime} \mathrm{W}$.

Other locations. A total of 46 samples of S. cryptandrus positive for seed gall nematodes were collected from 25 sites in West Central Idaho (Fig. 1).

Type materials. Holotype female (UCDNC 5258), paratype females, males and juveniles (UCDNC 5259-5274) were deposited in the Nematode Collection of University of California, Davis, USA.

Molecular analysis and ITS rRNA gene. Analysis of 330 ITS sequences of Afrina sporoboliae sp. n. extracted from $S$. cryptandrus collected from 25 populations in Idaho, revealed two haplotypes, designated Ail and Ai2, accession numbers MG321213 and MG321214, respectively (Table 1). These two haplotypes differed by only one segregating site and the nucleotide change was a transition $(\mathrm{G} \leftrightarrow \mathrm{A})$. Haplotype $A i 1$ was the most frequent and found in $97 \%$ of the sequences. Afrina sporoboliae sp. n. differed from Afrina wevelli
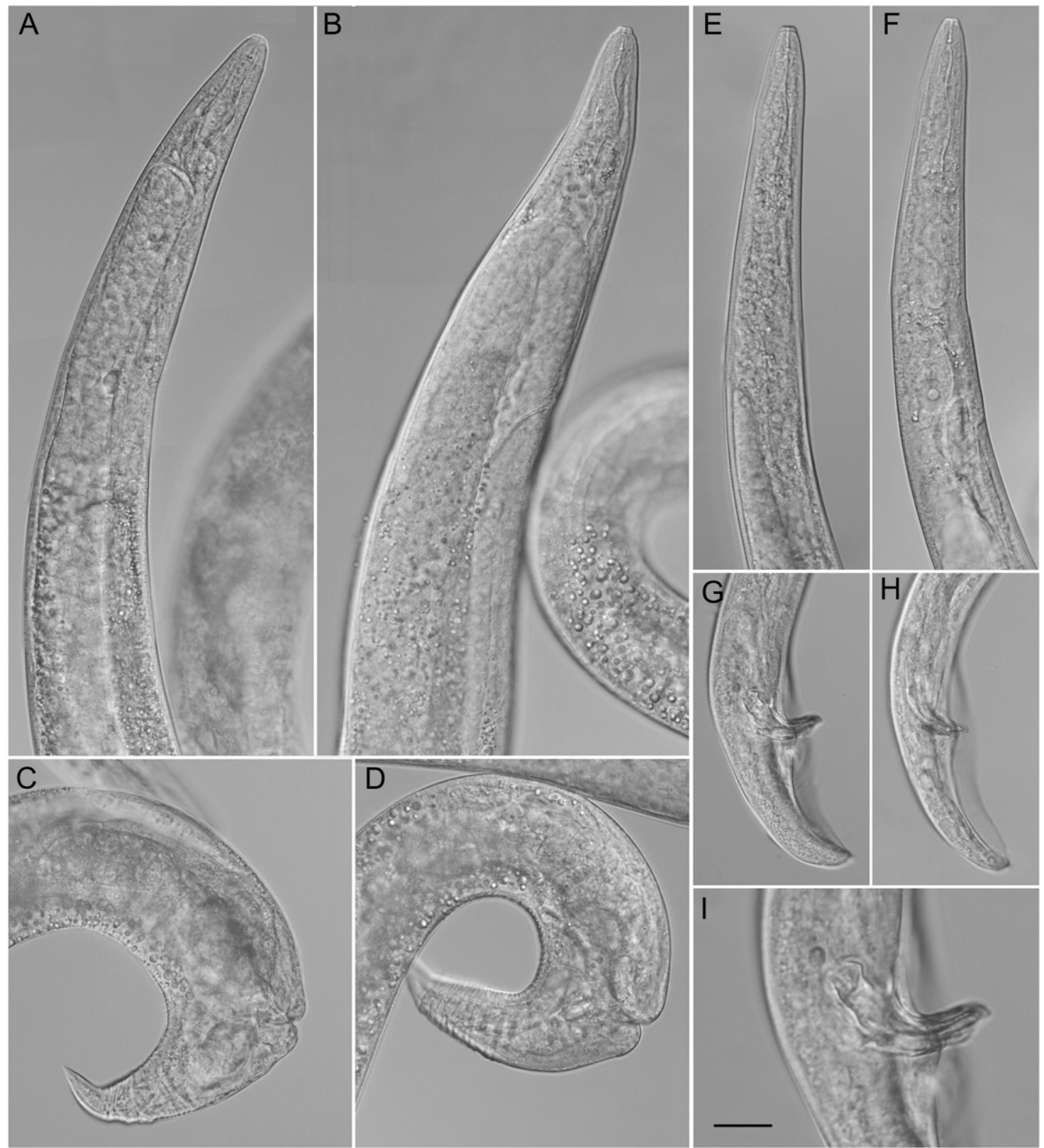

Fig. 5. Afrina sporoboliae sp. n.: $\mathbf{A}$ and $\mathbf{B}$, anterior ends of females; $\mathbf{C}$ and $\mathbf{D}$, posterior ends of females; $\mathbf{E}$ and $\mathbf{F}$, anterior ends of males; $\mathbf{G}$ and $\mathbf{H}$, posterior ends of males; and I, spicules with gubernaculum. Scale bar: A to $\mathbf{H}, 20 \mu \mathrm{m} ; \mathbf{I}, 10 \mu \mathrm{m}$. 
(KU052862) in 3.4 and 3.5\% (23 to $24 \mathrm{bp).} \mathrm{Sequences} \mathrm{of} \mathrm{Anguina}$ agrostis showed two haplotypes, designated Aal and Aa2 (MG321216 and MG321217, respectively). There was one segregating site difference between these two haplotypes and the nucleotide change was a transversion $(\mathrm{T} \leftrightarrow \mathrm{G})$. Analysis of Anguina agropyronifloris extracted from Agropyron smithii revealed a unique haplotype, designated as As 1 (MG321215). Alignment of Ail and Ai2 haplotype sequences of Afrina sporoboliae sp. n., new sequences of Anguina agrostis and Anguina agropyronifloris with sequences from other anguinids and Orrina phyllobia downloaded from GenBank contained 54 sequences, $829 \mathrm{bp}$ in length. Phylogenetic relationships within Anguinidae is given in Figure 7. Afrina sporoboliae sp. n. formed a highly supported clade $(\mathrm{PP}=95)$ with Afrina wevelli and an undescribed anguinid nematode.
The D2-D3 regions of the $28 S$ nuclear rRNA gene. Analysis of the D2-D3 region was performed using 60 sequences obtained from 6 of the 25 populations positive for Afrina sporoboliae sp. n. Alignment of the sequences revealed two segregating sites and three haplotypes, designated Aidl, Aid2, and Aid3 (MG321212, MG321211, and MG321210, respectively) (Table 1). Haplotype Aid1 was the most frequent, found in $92 \%$ of the sequences, and haplotypes Aid 2 and Aid 3 were found in 5 and $3 \%$ of the sequences, respectively. Haplotype Aidl and Aid 2 differed by only one segregating site and the nucleotide change was a transition $(\mathrm{C} \leftrightarrow \mathrm{T})$. In contrast, haplotype Aidl 1 and Aid 3 differed by two segregating sites and the changes were transitions $(\mathrm{C} \leftrightarrow \mathrm{T})$. Haplotype Aid2 and Aid3 differed by only one segregating site and the nucleotide change was a transition $(\mathrm{C} \leftrightarrow \mathrm{T})$.

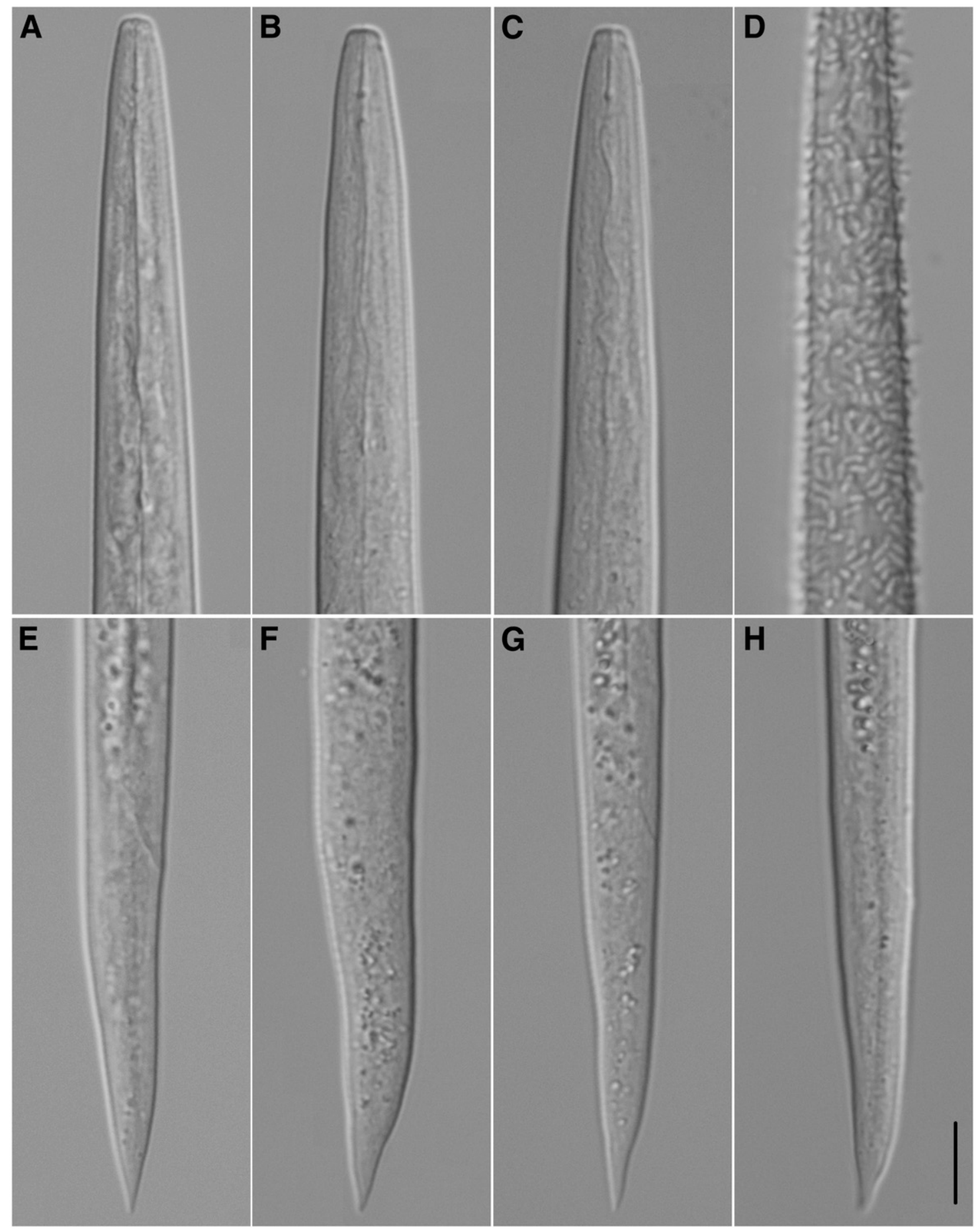

Fig. 6. Afrina sporoboliae sp. n.: A to $\mathbf{C}$, anterior ends of second-stage juveniles; $\mathbf{D}$, juvenile body covered by bacteria; $\mathbf{E}$ to $\mathbf{H}$, posterior ends of second-stage juveniles. Scale bar $=10 \mu \mathrm{m}$. 
Analysis of Anguina agropyronifloris extracted from Agropyron smithii revealed a unique haplotype, designated Asdl (MG321206). Alignment of the sequences of Anguina agrostis isolated from Agrostis sp. showed two haplotypes, labeled Aad1 and Aad2 (MG321207 and MG321207, respectively). These two haplotypes differed by one segregating site and the nucleotide change was a transversion $(\mathrm{G} \leftrightarrow \mathrm{C})$.

The D2-D3 of 28S rRNA gene alignment consisted of 22 sequences, $724 \mathrm{bp}$ in length, including seven new sequences of four anguinid species and two outgroups. Afrina sporoboliae sp. n. was in a highly supported clade ( $\mathrm{PP}=99)$ with Heteroanguina graminophila (Fig. 8).

Cox 1 of the mtDNA gene. Forty segregating sites were found in the coxl gene sequence and seven haplotypes designated as $\mathrm{H} 1$ to $\mathrm{H} 7$ were determined (MG321198 to MG321204). There was only one haplotype in 18 sites, two different haplotypes in six sites, and three different haplotypes in one site (Table 1). A unique haplotype (MG321205) was identified in 10 sequences of Anguina agrostis found in Agrostis sp.
A minimum-spanning network estimated among the 25 populations of the seed gall nematodes revealed that haplotypes $\mathrm{H} 1$ and $\mathrm{H} 2$ represented 39 and $37 \%$, respectively, of sampled nematodes and differed by one mutation (Fig. 9). A third haplotype (H3) represented $15 \%$ of sampled nematodes and differed from haplotype $\mathrm{H} 2$ by 32 mutations. Haplotypes H4, H5, H6, and H7 represented $9 \%$ of sampled nematodes and differed from haplotype $\mathrm{H} 2$ by one, five, one, and two segregating sites, respectively (Fig. 9). Haplotypes $\mathrm{H} 1$ and $\mathrm{H} 2$ were found in 12 and 11 populations, respectively. Haplotype $\mathrm{H} 3$ and $\mathrm{H} 5$ were found in five and two populations, respectively, and $\mathrm{H} 4, \mathrm{H} 6$, and $\mathrm{H} 7$ were found in one population each. None of the haplotypes were shared among all 25 populations.

Alignment of the 270,658-bp-long coxl sequences demonstrated that sequence divergence ranged from 0 to $5.2 \%$ (0 to $34 \mathrm{bp}$ ). The greatest genetic diversity was observed in population S25 $(h=$ $0.6222, \pi=0.0203$ ), and no genetic diversity was observed in 18 populations (Table 1). Forty positions were variable among the seven

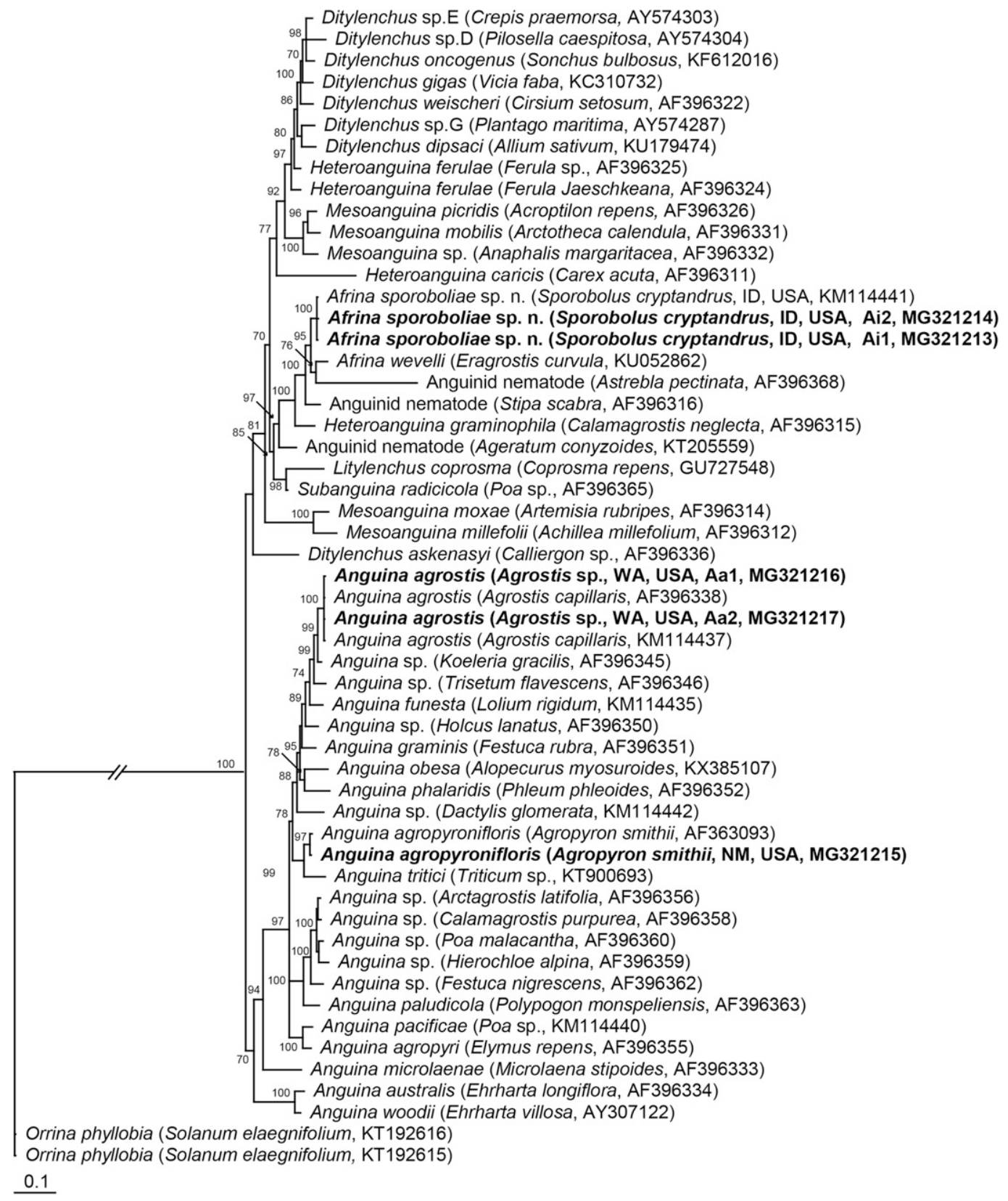

Fig. 7. Phylogenetic relationships among the family Anguinidae. Bayesian 50\% majority rule consensus tree from two runs with four chains as inferred from analysis of the internal transcribed spacer rRNA gene sequence alignment under the GTR + I + G model. Posterior probabilities equal to or more than $70 \%$ are given for appropriate clades. Original sequences are indicated by bold font. 
haplotypes; the majority of mutations (31) took place in the third base and just nine mutations took place in the first base. The nucleotide sequences of the seven haplotypes were converted into amino acid sequences and the analysis showed a unique amino acid change. The nonsynonymous mutation occurred in haplotype H6, where methionine was replaced by leucine.

AMOVA analysis of the partial coxl mtDNA gene of Afrina sporoboliae $\mathrm{sp}$. n. showed that most of the variation was among populations $(78.6 \%)$ with a high $F_{\mathrm{ST}}$ value $\left(F_{\mathrm{ST}}=0.78618\right)$ and a significant $P$ value $(P<0.001)$ (Table 2$)$.

\section{DISCUSSION}

The dropseed gall-forming nematode Afrina sporoboliae sp. n. is associated with seed galls on Sporobolus cryptandrus (Chloridoideae) and is the fifth species described in the genus Afrina. Phylogenetic analyses indicated that this new species formed a clade with Afrina wevelli, which induces seed galls on Eragrostis spp. (Chloridoideae), and two unidentified anguinid species that form seed galls on Astrebla pectinata (Chloridoideae) and Stipa scabra (Pooideae), respectively. These latter hosts are from Australia and both unidentified nematodes are also likely members of the genus Afrina. Three other Afrina species were not included in the analysis: Afrina spermophaga and Afrina hyparrheniae form seed galls on the grasses Saccharum spontaneum (Panicoideae) and Hyparrhenia spp. (Panicoideae), respectively, whereas Afrina tumefaciens induces galls on stems, leaves, and in flower heads of Cynodon transvaalensis (Chloridoideae).

The identification of Afrina sporoboliae sp. n. in Idaho is the third report of an Afrina species in North America and the first report of this genus in a natural plant population on this continent. Two previous records included Afrina spermophaga, which was reported from plants grown in Virginia, but from seeds originally collected in Turkmenistan (Steiner 1937), and Afrina wevelli recently reported by S. Song and J. Yi (unpublished data) from the United States in the GenBank under the accession number KU052862.

Intraspecific diversity among the seven cox 1 haplotypes of Afrina sporoboliae sp. $\mathrm{n}$. found in Idaho ranged from 0 to $5.2 \%$, which is within a normal range of intraspecific variation for plant parasitic nematodes. For example, intraspecific nucleotide sequence variation for Ditylenchus gigas was $2.9 \%, D$. dipsaci was $4 \%$ (Skwiercz et al. 2017), Longidorus helveticus was 7.3\% (Kumari and Subbotin 2012), Xiphinema californicum was $8.7 \%$ (Orlando et al. 2016), $X$. americanum s. str. was $10.0 \%$ (Orlando et al. 2016), and L. orientalis was $15.5 \%$ (Subbotin et al. 2015). Many factors, including geographical and environmental ones, were found to influence genetic diversity, enhance gene exchange, and lead to greater genetic diversity (Storfer et al. 2010). Idaho is covered from north to south by the Rocky Mountains and contains dozens of individual mountain ranges. Geographic isolation by mountains may explain the high genetic diversity among populations of the dropseed gall forming nematode. We did not find a significant positive relationship between genetic and geographic distance, suggesting the possibility of strong dispersal of this species across the study area. For example, the geographic distances between S4 and $\mathrm{S} 11$ or $\mathrm{S} 12$ collection sites were relatively small, but the genetic differences between their haplotypes were significant. The sampling area in this study emphasized roadside populations and movement of the host and nematode (and bacterium) could be influenced by this traffic.

In this study we also provide comprehensive phylogeny of the family Anguinidae based on the ITS rRNA gene sequences. Groupings of some species were congruent to those published by Subbotin et al. (2004). The resulting phylogenetic analysis also revealed monophyly of the genera Afrina and Anguina and paraphyly of the genera Ditylenchus, Mesoanguina, and Heteroanguina. Representatives of the genus Ditylenchus clustered within Heteroanguina ferulae. Heteroanguina graminophila is a sister taxon to the clade with the genus Afrina and two unidentified anguinids likely belonging to this genus. Heteroanguina graminophila induces leaf and stem galls on grasses and is distributed in some European countries, Canada, and Minnesota, Iowa, Ohio, and Wisconsin, USA (Krall 1991).

Since these nematodes are host-specific, the distribution of Afrina sporoboliae sp. $\mathrm{n}$. is determined by distribution of its plant host, Sporobolus cryptandrus. Sand dropseed is native to North

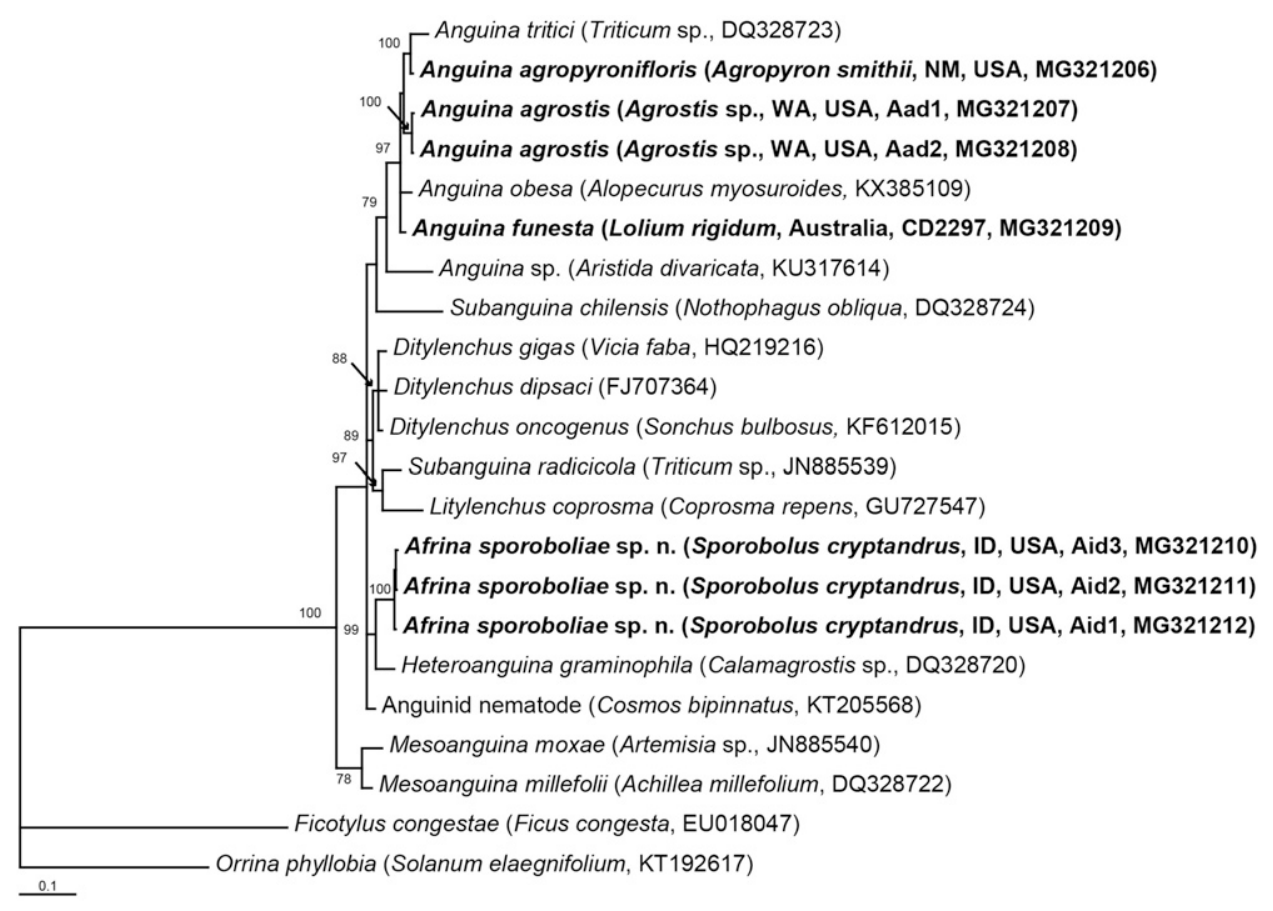

Fig. 8. Phylogenetic relationships within representatives of the family Anguinidae. Bayesian $50 \%$ majority rule consensus tree from two runs with four chains as inferred from analysis of the D2-D3 of 28S rRNA gene sequence alignment under the GTR + I + G model. Posterior probabilities equal to or more than 70\% are given for appropriate clades. Original sequences are indicated by bold font. 
America and is widespread throughout southern Canada, most of the United States, and northern Mexico. In a phylogenetic analysis of the Sporobolinae using sequence data from four plastid regions and the ITS, Sporobolus cryptandrus was placed with other four species in the North American clade K section of Cryptandri (Peterson et al. 2014). The five species in the $S$. cryptandrus complex are all native to the southwestern United States and Mexico, and share several morphological features. Species in this complex tend to occur in saltdesert scrub and pinyon-juniper woodlands in slightly saline environments (Peterson et al. 2003). Consequently, it seems likely that the dropseed gall-forming nematode may have wider distribution in North America than has been known until now, but this remains to be determined.

Afrina sporoboliae sp. n. is also associated with and potentially a vector of a new species of Rathayibacter causing bacterial head blight of Sporobolus cryptandrus (B. K. Schroeder and T. D. Murray, unpublished data). Most of the sand dropseed collections in this study that were positive for Afrina sporoboliae also contained light-colored seed galls that yielded nearly pure cultures of a Grampositive bacterium. Based on sequence analysis of the $16 \mathrm{~S}$ rRNA, these bacteria belong to the genus Rathayibacter. Several other Anguina species are vectors of Rathayibacter species in other grass hosts, where they cause bacteriosis diseases (Murray et al. 2017). The presence of this and other seed gall nematodes in the United States raises questions about their ability to serve as vectors of Rathayibacter species, especially $R$. toxicus, since the relationship between nematode and bacterium is not entirely specific (Murray et al. 2017). Seed gall nematodes are important quarantine pests that are internationally regulated in many countries, including the United States. Consequently, the presence of new and unidentified species raises concerns over the lack of specific detection and discrimination methods especially for seed trade (Meng et al. 2012). Additional research is needed to delineate the geographic distribution of Afrina sporoboliae sp. n. and to determine whether other unidentified seed gall nematodes are present in the United States. Likewise, additional information is needed on the association of unidentified Rathayibacter species with these nematodes.

In summary, a new species of Afrina, Afrina sporoboliae sp. n., and a possible new species of Rathayibacter were found in association with $S$. cryptandrus in Idaho. Future work on establishing greenhouse pot cultures with seed gall nematodes will enable us to study the behavior of these nematodes and develop a system to study their interaction with Rathayibacter spp.

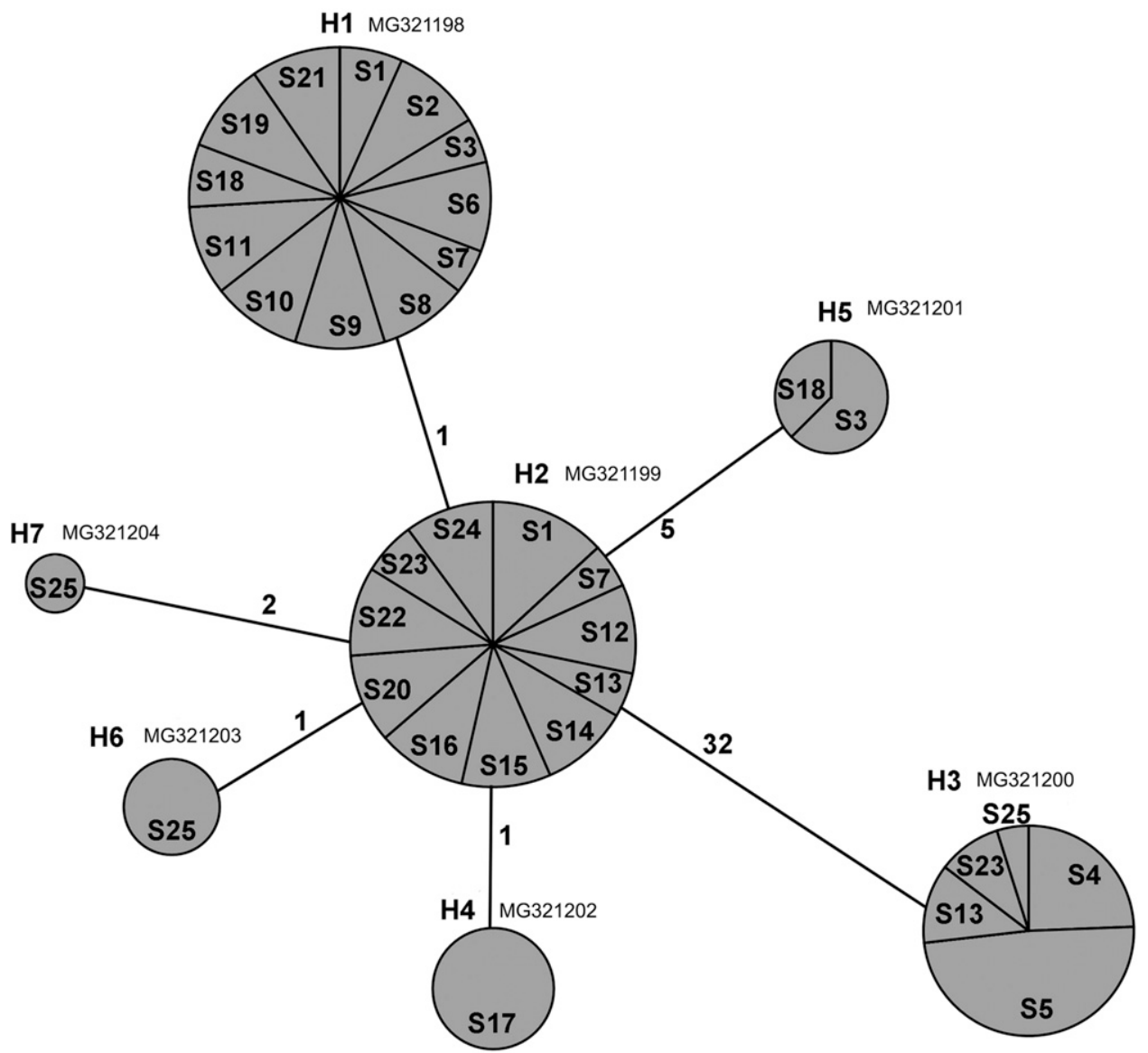

Fig. 9. Minimum-spanning haplotype network of the partial coxl mtDNA gene sequences of Afrina sporoboliae sp. $\mathrm{n}$. from the 25 collection sites (S1 to S25) found in Sporobolus cryptandrus in Idaho, USA. Each circle represents a haplotype (H1 to H7) whose size is proportional to the haplotype frequency. Numbers of changes between haplotypes are given in brackets on appropriate branches.

TABLE 2. Analysis of molecular variance using the Tamura and Nei (1993) distance method based on sequence of the coxl mtDNA gene of Afrina sporoboliae sp. n. collected from Sporobolus cryptandrus in Idaho ${ }^{\mathrm{a}}$

\begin{tabular}{lcccccc}
\hline Source of variation & Degrees of freedom & Sum of squares & Variance components & Percentage of variation & $F_{\text {ST }}$ & $P$ \\
\hline Among populations & 24 & 1039.6 & 3.922 & 78.6 & 0.78618 \\
Within populations & 245 & 261.4 & 1.067 & 21.4 & $<0.001$ \\
\hline
\end{tabular}

a Analysis was performed with 10,100 permutations. Gamma shape parameter $=0$. 


\section{ACKNOWLEDGMENTS}

We thank E. Ivanova for help in drawings and I. T. Riley for supplying Anguina funesta materials.

\section{LITERATURE CITED}

Bertozzi, T., and Davies, K. 2009. Anguina paludicola sp. n. (Tylenchida: Anguinidae): The nematode associated with Rathayibacter toxicus infection in Polypogon monspeliensis and Lachnagrostis filiformis in Australia. Zootaxa 2060:33-46.

Brzeski, M. W. 1981. The genera of Anguinidae (Nematoda, Tylenchida). Rev. Nematol. 4:23-34.

Chatel, D. L., Wise, J. L., and Marfleet, A. G. 1979. Ryegrass toxicity organism found on other grasses. J. Agric. W. Aust. 20:89.

Chizhov, V. N., and Subbotin, S. A. 1985. Revision of the nematode from the subfamily Anguininae (Nematoda, Tylenchida) on the basis of their biological characteristics. Zool. Zhurnal 64:1476-1486.

Chizhov, V. N., and Subbotin, S. A. 1990. Phytoparasitic nematodes of subfamily Anguininae (Nematoda, Tylenchida). Morphology, trophic specialization, taxonomic. Zool. Zhurnal 69:15-26.

Cobb, N. A. 1932. Nematosis of a grass of the genus Cynodon caused by a new nema of the genus Tylenchus Bast. J. Wash. Acad. Sci. 22:243-245.

Corbett, D. C. M. 1966. Central African nematodes. III. Anguina hyparrheniae n. sp. associated with "witches" broom of Hyparrhenia spp. Nematologica 12:280-286.

De Grisse, A. 1969. Rédescription ou modifications de quelques techniques utilisées dans l'étude des nématodes phytoparasitaires. Meded. Rijks. Landbouw Wetenschappen Gent 34:351-369.

Edgar, J. A., Frahn, J. L., Cockrum, P. A., Anderton, N., Jago, M. V., Culvenor, C. C. J., Jones, A. J., Murray, K., and Shaw, K. J. 1982. Corynetoxins causative agents of annual ryegrass toxicity; Their identification as tunicamycin group antibiotics. J. Chem. Soc. Chem. Commun. 4: 222-224.

Excoffier, L., and Lischer, H. E. L. 2010. Arlequin suite ver. 3.5: A new series of programs to perform population genetics analyses under Linux and Windows. Mol. Ecol. Resour. 10:564-567.

Fisher, J., Dube, A., and Watson, C. 1979. Distribution in south Australia of Anguina funesta, the nematode associated with annual ryegrass toxicity. Aust. J. Exp. Agric. 19:48.

Fortuner, R., and Maggenti, A. R. 1987. A reappraisal of Tylenchina (Nemata). 4. The family Anguinidae Nicoll, 1935 (1926). Rev. Nematol. 10:163-176.

Futai, K., and Kanzaki, N. 2002. A PCR primer set for determination of phylogenetic relationships of Bursaphelenchus species within the xylophilus group. Nematology 4:35-41.

Huelsenbeck, J. P., and Ronquist, F. 2001. MrBAYES: Bayesian inference of phylogenetic trees. Bioinformatics 17:754-755.

Joyce, S. A., Reid, A., Driver, F., and Curran, J. 1994. Application of polymerase chain reaction (PCR) methods to identification of entomopathogenic nematodes. Pages: 178-187 in: COST 812 Biotechnology: Genetics of Entomopathogenic Nematode-Bacterium Complexes. A. Burnel, M. R.-U. Ehlersl, and J. P. Masson, eds. Proceedings of Symposium and Workshop, St. Patrick's College, Maynooth, Kildare, Ireland. European Commission, DG XII, Luxembourg.

Krall, E. L. 1991. Wheat and grass nematodes: Anguina, Subanguina, and related genera. Pages 721-760 in: Manual of Agricultural Nematology. W. R. Nickle, ed. Marcel Dekker, Inc., New York.

Kumari, S., and Subbotin, S. A. 2012. Characterization of Longidorus helveticus (Nematoda: Longidoridae) from the Czech Republic. Eur. J. Plant Pathol. 133:923-933.

Leigh, J. W., and Bryant, D. 2015. POPART: Full-feature software for haplotype network construction. Methods Ecol. Evol. 6:1110-1116.

Li, W., Yan, Z., Nakhla, M. K., and Skantar, A. M. 2015. Real-time PCR for detection and identification of Anguina funesta, A. agrostis, A. tritici, and A. pacificae. Plant Dis. 99:1584-1589.

Librado, P., and Rozas, J. 2009. DnaSP v5: A software for comprehensive analysis of DNA polymorphism data. Bioinformatics 25:1451-1452.

McKay, A. C., and Ophel, K. M. 1993. Toxigenic Clavibacter/Anguina associations infecting grass seedheads. Annu. Rev. Phytopathol. 31: 151-167.

Medina-Gómez, E., Ramírez-Suárez, A., Cuevas-Ojeda, J., and Martínez-Gómez, D. 2016. Identificación y análisis filogenético del nematodo foliar Orrina phyllobia afectando Solanum elaeagnifolium Cav. en Guanajuato, México. Rev. Mex. Fitopatol. 34:184-199.

Meng, S., Alderman, S., Fraley, C., Fraley, R., Sun, F., and Osterbauer, N. 2012. Identification of Anguina funesta from annual ryegrass seed lots in Oregon. Plant Health Progress.
Mobasseri, M., Pedram, M., Pourjam, E., and Bertozzi, T. 2017. Description of a new species of seed-gall nematode, Anguina obesa n. sp. (Nematoda: Anguinidae) from northern Iran, and its phylogenetic relations with other species and genera. Eur. J. Plant Pathol. 148:423-434.

Murray, T. D., Schroeder, B. K., Schneider, W. L., Luster, D. G., Sechler, A., Rogers, E. E., and Subbotin, S. A. 2017. Rathayibacter toxicus, other Rathayibacter species inducing bacterial head blight of grasses, and the potential for livestock poisonings. Phytopathology 107:804-815.

Nylander, J. A. A. 2002. MrModeltest 2.2. Evolutionary Biology Centre, Uppsala University, Uppsala, Sweden.

OPIS (Offshore Pest Information System). 2012. The 2012 Prioritized Offshore Pest List. USDA-APHIS. http://www.aphis.usda.gov/plant_health/ plant_pest_info/pest_detection/downloads/farmbill/PrioritizedOffshorePestList. pdf

Orlando, V., Chitambar, J. J., Dong, K., Chizhov, V. N., Mollov, D., Bert, W., and Subbotin, S. A. 2016. Molecular and morphological characterisation of Xiphinema americanum group species (Nematoda: Dorylaimida) from California, USA and other regions and co-evolution of bacteria from the genus Candidatus Xiphinematobacter with nematodes. Nematology 18: 1015-1043.

Peterson, P. M., Hatch, S. L., and Weakley, A. S. 2003. Sporobolus R. Br. Pages 115-139 in: Flora of North America North of Mexico, vol. 25, Magnoliophyta: Commelinidae (in part): Poaceae, part 2. M. E. Barkworth, K. M. Capels, S. Long, and M. B. Piep, eds. Oxford University Press, New York.

Peterson, P. M., Romaschenko, K., Arrieta, Y. H., and Saarela, J. M. 2014. A molecular phylogeny and new subgeneric classification of Sporobolus (Poaceae: Chloridoideae: Sporobolinae). Taxon 63:1212-1243.

Powers, T. O., Szalanski, A. L., Mullin, P. G., Harris, T. S., Bertozzi, T., and Griesbach, J. A. 2001. Identification of seed gall nematodes of agronomic and regulatory concern with PCR-RFLP of ITS1. J. Nematol. 33: 191-194.

Price, P. C., Fisher, J. M., and Kerr, A. 1979. On Anguina funesta n. sp. and its association with Corynebacterium sp., in infecting Lolium rigidum. Nematologica 25:76-85.

Riley, I. T. 1987. Serological relationships between strains of Coryneform bacteria responsible for annual ryegrass toxicity and other plant-pathogenic corynebacteria. Int. J. Syst. Bacteriol. 37:153-159.

Riley, I. T., and McKay, A. C. 1990. Specificity of the adhesion of some plant pathogenic micro-organisms to the cuticle of nematodes in the genus Anguina (Nematoda: Anguinidae). Nematologica 36:90-103.

Riley, I. T., and Reardon, T. B. 1995. Isolation and characterization of Clavibacter tritici associated with Anguina tritici in wheat from Western Australia. Plant Pathol. 44:805-810.

Riley, I. T., Schmitz, A., and de Silva, P. 2001. Anguina australis, a vector for Rathayibacter toxicus in Ehrharta longiflora. Australas. Plant Pathol. 30: 171-175.

Siddiqi, M. R. 2000. Tylenchida Parasites of Plants and Insects, 2nd ed. CABI Publishing, Wallingford, UK.

Skwiercz, A. T., Kornobis, F. W., Winiszewska, G., Przybylska, A., Obrępalska-Stęplowska, A., Gawlak, M., and Subbotin, S. A. 2017. Ditylenchus laurae sp. n. (Tylenchida: Anguinidae) from Poland - A new species of the $D$. dipsaci complex associated with a water plant, Potamogeton perfoliatus L. Nematology 19:197-209.

Steiner, G. 1937. Opuscula miscellanea nematologica. Proc. Helminthol. Soc. Wash. 4:33-38.

Storfer, A., Murphy, M. A., Spear, S. F., Holderegger, R., and Waits, L. P. 2010. Landscape genetics: Where are we now? Mol. Ecol. 19:3496-3514.

Subbotin, S. A., Krall, E. L., Riley, I. T., Chizhov, V. N., Staelens, A., De Loose, M., and Moens, M. 2004. Evolution of the gall-forming plant parasitic nematodes (Tylenchida: Anguinidae) and their relationships with hosts as inferred from internal transcribed spacer sequences of nuclear ribosomal DNA. Mol. Phylogenet. Evol. 30:226-235.

Subbotin, S. A., and Riley, I. T. 2012. Stem and gall forming nematodes. Pages 521-577 in: Practical Plant Nematology. R. Manzanilla-Lopez and M. Marban-Mendoza, eds. Mundi Prensa, Mexico.

Subbotin, S. A., Stanley, J. D., Ploeg, A. T., Tanha Maafi, Z., Tzortzakakis, E. A., Chitambar, J. J., Palomares-Ruis, J. E., Castillo, P., and Inserra, R. N. 2015. Characterisation of populations of Longidorus orientalis Loof, 1982 (Nematoda: Dorylaimida) from date palm (Phoenix dactylifera L.) in the USA and other countries and incongruence of phylogenies inferred from ITS1 rRNA and coxl genes. Nematology 17: 459-477.

Subbotin, S. A., Vovlas, N., Crozzoli, R., Sturhan, D., Lamberti, F., Moens, M., and Baldwin, J. 2005. Phylogeny of Criconematina Siddiqi, 1980 (Nematoda: Tylenchida) based on morphology and D2-D3 expansion segments of the 28S-rRNA gene sequences with application of a secondary structure model. Nematology 7:927-944. 
Tamura, K., and Nei, M. 1993. Estimation of the number of nucleotide substitutions in the control region of mitochondrial DNA in human and chimpanzees. Mol. Biol. Evol. 10:512-526.

Tamura, K., Stecher, G., Peterson, D., Filipski, A., and Kumar, S. 2013. MEGA6: Molecular evolutionary genetics analysis version 6.0. Mol. Biol. Evol. 30:2725-2729.

Thompson, J. D., Gibson, T. J., Plewniak, F., Jeanmougin, F., and Higgins, D. G. 1997. The CLUSTAL_X windows interface: Flexible strategies for multiple sequence alignment aided by quality analysis tools. Nucleic Acids Res. 25:4876-4882.
Van den Berg, E. 1985. Notes on the genus Afrina Brzeski, 1981 (Anguinidae: Nematoda) with description of new and known species. Phytophylactica 17: 69-79.

Zhao, Z. Q., Davies, K., Alexander, B., and Riley, I. T. 2011. Litylenchus coprosma gen. n., sp. n. (Tylenchida: Anguinata), from leaves of Coprosma repens (Rubiaceae) in New Zealand. Nematology 13:29-44.

Zheng, J., Subbotin, S. A., Waeyenberge, L., and Moens, M. 2000. Molecular characterisation of Chinese Heterodera glycines and $H$. avenae populations based on RFLPs and sequences of rDNA-ITS regions. Russ. J. Nematol. 8: 109-113. 